\title{
ПСИХОЛОГІЧНІ ЧИННИКИ ОСОБИСТОСТІ ПЕРЕКЛАДАЧА: ОГЛЯД ПРОБЛЕМИ
}

\author{
ОЛЬГА ЛЕГКА-ПАУЛЬ \\ Університет імені Адама Міцкевича, Познань - Польща \\ olya.lehka@gmail.com \\ PSYCHOLOGICZNE CZYNNIKI OSOBOWOŚCI TŁUMACZA: \\ PRZEGLĄD TEMATU \\ OLHA LEHKA-PAUL \\ Uniwersytet imienia Adama Mickiewicza, Poznań — Polska
}

\begin{abstract}
STRESZCZENIE. Antropologiczny czynnik za pośrednictwem psychologicznych oraz kognitywnych mechanizmów odgrywa ważną rolę zarówno w procesie thumaczenia, jak i w produkcie końcowym. Identyfikacja trudności w tekście, poszukiwanie odpowiedników, poczucie niepewności razem z koniecznością podjęcia decyzji, za które tłumacz jest odpowiedzialny — niemal każdy etap pracy nad tłumaczeniem przewiduje zastosowanie nie tylko kompetencji zawodowych, ale także pewnych funkcji psychologicznych. Celem artykułu jest wyznaczenie wpływu psychologicznych oraz kognitywnych czynników osobowości tłumacza na strategię tłumaczenia oraz tekst docelowy. Wyniki badań mogą znaleźć praktyczne zastosowanie $\mathrm{w}$ dydaktyce thumaczenia, a mianowicie - nowatorskie podejście do przygotowania przyszłych tłumaczy zawodowych.
\end{abstract}

\section{PSYCHOLOGICAL FEATURES OF THE TRANSLATOR'S PERSONALITY: A REVIEW OF THE ISSUE}

\section{OLHA LEHKA-PAUL}

Adam Mickiewicz University, Poznań — Poland

ABSTRACT. The anthropological factor through the activation of the psychological and cognitive mechanisms plays an important role in both the process and product of translation. Identifying the problematic areas, searching for correspondents, feeling uncertain and yet bound to make a decision, the responsibility for which lies on the translator — roughly each stage of working on translation involves not only the use of professional competences, but also certain psychological functions. The present project aims at tracing the impact of the psychological and cognitive characteristics of the translator's personality on translation strategy and target text. The practical implications of the study concern translation didactics, offering a novel approach to the training of future translators.

$\mathrm{B}$ ідколи перекладознавство здобуло статус самостійної дисципліни, виділяють два основні підходи до об'єкта дослідження - “переклад” як процес та "переклад" як кінцевий продукт. Сполучною ланкою в цьому дуалізмі є агент перекладу — людина, здатна до міжмовного, міжкультурного й міжперсонального посередництва, експерт, професійні компетенції якого повинні охопити всеможливі труднощі різних типів завдань. Так, німецький учений В. Вільсс, аналізуючи процес перекладу, який здійснюють студенти, назвав переклад "комплексною когнітивною діяльністю", а фінський перекладо-

1 W. Wils s, Knowledge and skills in translator behavior, Amsterdam 1996, p. 37. 
знавець Р. Яаскелаїнен зауважила, що „існує психологічне пояснення для кожного явища в перекладі”'. Якими ж психологічними та когнітивними механізмами послуговується перекладач і в який спосіб вони впливають на процес та продукт перекладу?

Звісно, це питання вимагає глибокого міждисциплінарного дослідження, а відповідь на нього виходить за межі однієї розвідки. Саме тому метою цієї статті є загальний огляд проблеми особистості перекладача: 1) окреслення ii місця в сучасному перекладознавстві, 2) простеження еволюції наукових методів та підходів, 3) обговорення результатів експериментальних спроб і 4) визначення ділянок, що потребують детального вивчення.

У 1988 р. Дж. С. Голмс ${ }^{3}$ уперше публікує свої думки про необхідність установлення перекладознавства на рівні з іншими філологічними науками й навіть пропонує доволі чітку структуру нової дисципліни. Нідерландський поет та перекладач вирізняє дві основні гілки в перекладознавстві: т. зв. “чисте”, в основному теоретичне та описове, і прикладне, що керується практичними цілями. Саме до першої гілки в 2009 р. Е. Честерман ${ }^{4}$ рекомендує додати "науку про перекладача”, що об’єднувала б і доповнювала аналіз вихідного тексту, процесу та функцій перекладу. Хоч ця ідея і не отримала загального визнання, проте знайшла своїх прихильників, насамперед серед тих перекладознавців, які займаються вивченням ментальних явищ у процесі перекладу. Це ціла низка науковців, які з 80-их років минулого сторіччя намагаються зазирнути в "чорну скриньку" перекладацької свідомості за допомогою різних експериментальних методів - від протоколів до окулографів, про які детальніше йтиметься далі в тексті.

3 іншого боку, упровадження "науки про перекладача" змогло б допомогти пояснити індивідуальні тенденції, які важко змістити в рамки порівняльного аналізу тексту - зокрема, вибір стратегії перекладу, шліфування власного стилю та професійних навичок, що відображаються в тексті перекладу.

Таким чином, намагаючись зрозуміти психологічні та когнітивні чинники особистості перекладача, можна спробувати поєднати два основні підходи до об'єкта дослідження за допомогою детального аналізу процесу перекладу та оцінювання якості вихідного тексту. Потребу комплексного аналізу неодноразово висловлювали такі сучасні перекладознавці, як С. Тіркконен-Кондіт $(1986)^{5}$, М. Снелл-Горнбі $(1988)^{6}$, М. Тимочко (2005) лаїнен $(2012)^{9}$ та Ш. О’Браян $(2013)^{10}$, однак мало хто до цього часу наважувався на таку амбітну спробу.

2 R. Jääskeläinen, Translation psychology, [in:] Y. Gambier, L. van Doorslaer, Handbook of Translation Studies, Amsterdam 2012, vol. 3, p. 191-197.

3 J. S. Holmes, The Name and Nature of Translation Studies, [in:] J. S. Holmes (ed.), Translated! Papers on Literary Translation and Translation Studies, Philadelphia/Amsterdam and Atlanta 1972 / 1988, p. 67-80.

4 A. Chesterman, The name and nature of Translator Studies, [in:] „Journal of Language and Communication Studies" 2009, No. 42, p. 13-22.

${ }^{5} \mathrm{~S}$. Tirk k onen-Condit, Empirical studies in translation: Textlinguistic and psycholinguistic perspectives, Joensuu 1986.

6 M. Snell-Hornby, Translation Studies: An integrated approach, Amsterdam 1988.

7 M. Tymoczko, Trajectories of research in Translation Studies, [in:] „Meta” 2005, Vol. 50, No. 4, p. 1085-1097.

8 B. W hy att, Translation as a human skill. From predisposition to expertise, Poznan 2012.

9 R. Jääskeläinen, Ibidem.

10 S. O'Bri en, The borrowers. Researching the cognitive aspects of translation, [in:] „Target” 2013, Vol. 25, No. 1, p. 5-17. 
Більшість попередніх досліджень не переслідувало глобальної мети описати особистість перекладача, а торкалось вужчих, конкретніших завдань, тому найзручніше класифікувати їх за предметом аналізу: 1) психологічні чинники, 2) когнітивні механізми, 3) професійні компетенції. Перший тип - вивчення психологічних характеристик особистості перекладача - найобширніший і найменш досліджений з усіх, а тому й знаходиться в центрі цієї розвідки.

Другий тип - пізнання когнітивних інструментів, якими послуговується перекладач - найпопулярніший і методологічно найрозвиненіший. Левова частка досліджень цього типу зосереджена на детальному аналізі процесу перекладу. Першим експериментальним методом уважається протокол “думка вголос", для запису якого перекладач озвучує свої думки під час перекладу. Цей метод запропонували К. Еріксон і Г. Саймон ${ }^{11}$ у 80 -х роках минулого століття як спосіб отримання процесуальних даних “з уст” самого перекладача, що мало б засвідчити використання конкретних ментальних механізмів. Тоді з'явились спроби пояснення перекладацької стратегії (У. Льоршер, 1991) ${ }^{12}$, творчих пошуків у перекладі (П. Куссмауль, 1995) ${ }^{13}$ та перебігу процесу загалом (В. Вільсс, 1996) ${ }^{14}$. Однак метод аналізу протоколів виявився досить обмеженим, оскільки, по-перше, перекладачі озвучували лише роботу над "проблемними місцями", а по-друге, скаржилися на штучність експерименту і незручність, яку відчували під час озвучення своїх думок. Саме тому наступним кроком було розроблення спеціальних комп'ютерних програм, що дають змогу цілковито відтворювати процес створення тексту на екрані. Цей метод дедалі частіше використовують у сучасних дослідженнях, оскільки він не вимагає від перекладача жодних додаткових зусиль. Найпопулярнішими програмами $€$ TranslogII ${ }^{15}$, Input $\log ^{16}$ i Scriptlog ${ }^{17}$. Найновішим доповненням до цих програм, а водночас і самостійним методологічним інструментом, є спеціальний пристрій, що фіксує рух зіниці - ай-трекер (інша назва — окулограф, з англійської “eyetracker”). Ще сто років тому вчені звернули увагу на особливості процесу читання, а саме - поведінку ока, що "перестрибує" через кілька слів, “біжить” уперед і повертається назад, коли з'являються проблеми з розумінням написаного. Так, 1980 p. М. Юст і П. Карпентер ${ }^{18}$ висунули гіпотезу “око-думка”, згідно з якою рух зіниці відображає когнітивну діяльність мозку, тобто око фіксується на тій ділянці тексту, над якою працює мозок. Слідкуючи за рухом зіниці, ай-трекер дає змогу вченим проаналізувати когнітивний ритм перекладача у процесі перекладу. Метод ай-трекінгу здобуває все більше прихильників серед перекладознавців, які

11 K. Ericsson, H. Simon, Verbal reports as data, [in:] „Psychological Review” 1980, Vol. 87, No. 3, p. 215-251.

${ }_{12}$ W. Löscher, Translation performance, translation process and translation strategies, Tuebingen 1991.

${ }_{13}$ P. Ku s s m a u 1, Training the Translator, Amsterdam 1995.

14 W. Wils s, Ibidem.

${ }^{15}$ A. L. J a k o b s e n, Investigating expert translators'processing knowledge, [in:] H. V. D a m, J. Engberg, H. Gerzymisch-Arbogast (eds.), Knowledge Systems and Translation, Berlin, Boston 2005, p.173-189.

${ }_{16}$ M. Leijten, L. Van Waes, Inputlog: New Perspectives on the Logging of On-Line Writing, [in:] K. P. H. Sullivan, E. Lindgren (eds.), Computer Keystroke Logging and Writing: Methods and Applications, Oxford 2006, p. 73-94.

17 S. Strömqvist, K. Holmqvist, V. Johansson, H. Karlsson, A. Wengelin, What keystroke logging can reveal about writing, [in:] K. P. H. Sullivan, E. Lindgren (eds.), Computer Keystroke Logging and Writing: Methods and Applications, Oxford 2006, p. 45-71.

${ }_{18}$ M. A. Just, P. A. Carpenter, A theory of reading: From eye fixations to comprehension, [in:] „Psychological Review” 1980, Vol. 87, No. 4, p. 329-354. 
віддавна прагнуть зрозуміти механізми “чорної скриньки" свідомості перекладача. Серед цікавих проектів за використанням ай-трекера - дослідження інструментів перекладацької пам'яті та когнітивного навантаження (Ш. О’Браян, $2006)^{19}$, читання для перекладу як особливого способу читання (А. Якобсен і К. Снсен, 2008) ${ }^{20}$, координацію процесів розуміння і продукції тексту (Б. Драгстед, 2008) ${ }^{21}$, розподіл когнітивного зусилля у процесі перекладу (Велплунд, $2011)^{22}$, класифікацію стилів перекладу (Б. Драгстед і М. Карл, 2013) ${ }^{23}$ та ін.

Третій тип дослідження особистості перекладача пов'язаний із вивченням його професійних компетенцій. Дві групи дослідників, іспанська РАСТЕ (від 2002 р.) та німецька TransComp (від 2007 р.), протягом кількох років працювали над створенням моделі перекладацьких компетенцій, проводячи експерименти над студентами напрямку “переклад” та перекладачами-практиками. Цікаво, що обидві групи визнають роль особистості в професії перекладача, розміщуючи психо-фізіологічні компоненти (РАСТЕ, 2003 ${ }^{24}$ ) та психо-фізичну диспозицію (С. Гопферіш і Р. Яаскелаїнен, 2009) ${ }^{25}$ в основі для подальшого розвитку професійних знань і навичок.

Таким чином, амбітність розгляду психологічних чинників особистості перекладача полягає не лише в поєднанні аналізу процесу і тексту перекладу, а й у перетині двох незалежних дисциплін - психології та перекладознавства. Використання основних теорій психології особистості для вивчення особистості перекладача розміщує дослідження в міждисциплінарному вимірі та ще більше ускладнює завдання.

Цікаво, що в підходах до психології особистості також існує дуалізм, що виник на підставі різних дефініцій настільки багатошарового поняття як “особистість". Тому з метою глибшого розуміння еволюції методів вивчення особистості перекладача передусім розглянемо, як до цієї проблеми підходять у психології.

Після спірної популярності методу психоаналізу 3. Фрейда зацікавлення психологією особистості в міжвоєнний період зменшилось, а відродилося знову після закінчення Другої світової війни. У той час з'явилась нагальна потреба у створенні нових робочих місць для чоловіків, а також для жінок, які почали повноцінно входити на ринок праці. Для передбачення поведінки людей у різних виробничих умовах, ефективного добору працівників, збільшення мотивації та покращення продуктивності штату психологи вивчали різноманіт-

${ }^{19}$ S. O’Brien, Eye-tracking and translation memory matches, [in:] „Perspectives: Studies in Translatology" 2006, No. 14, p. 185-203.

${ }^{20}$ A. L. Jakobsen, K. T. Hvelplund Jensen, Eye movement behaviour across four different types of reading task, [in:] S. Göpferich, Arnt L. Jakobsen, Inger M. Mees (eds.), Looking at Eyes: Eye-Tracking Studies of Reading and Translation Processing, Copenhagen 2008, p. 103-124.

21 B. Dragsted, I. G. Hansen, Comprehension and production in translation, [in:] S. Göpferich, Arnt L. Jakobsen, Inger M. Mees (eds.), Looking at Eyes: Eye-Tracking Studies of Reading and Translation Processing, Copenhagen 2008, p. 9-30.

${ }^{22} \mathrm{~K} . \mathrm{T}$. Hvelplund, Allocation of Cognitive Resources in Translation: An Eye-tracking and Key-logging Study, Copenhagen 2011.

${ }_{23}$ B. Dragsted, M. Carl, Towards a classification of translation styles based on eye-tracking and keylogging data, [in:] „Journal of Writing Research”2013, Vol. 5, No. 1, p. 133-158.

24 PACTE, Building a Translation Competence Model, [in:] F. Alves (ed.) Triangulating Translation, Amsterdam 2003, p. 43-66.

${ }_{25} \mathrm{~S} . \mathrm{G} o ̈ \mathrm{p} f \mathrm{erich}$, R. Jääskelä in en, Process research into the development of translation competence: where are we and where do we need to go? [in:] „Across Languages and Cultures” 2009, Vol. 10, No. 2, p. 169-191. 
ні елементи особистості - риси, характер, темперамент, психологічні функції, тощо ${ }^{26}$. Такий підхід до особистості згодом сформувався в окремий підрозділ під назвою “психологія праці", головним постулатом якої є твердження про те, що з огляду на домінантні риси та особливості характеру певні типи особистості краще виконуватимуть певні види діяльності, ніж інші. Це переконання $\epsilon$ ще одним доказом того, що необхідно вивчати діяльність перекладача в контексті психології особистості.

Згаданий раніше дуалізм у трактуванні психологічних чинників особистості - це спір між прихильниками теорії рис та теорії психологічних типів К. Юнга. Згідно з першою, риси вважаються стабільними внутрішніми чинниками, що притаманні людям у різних ситуаціях. ${ }^{27}$ Завдяки своїй відносній стабільності риси здатні передбачити моделі поведінки людини за різних обставин у різний час. Теорія рис бере свій початок з психолексичних досліджень, що базуються на відомій у психології лексичній гіпотезі, яку ще 1884 р. запропонував британський учений Ф. Гальтон - риси особистості як вагомі характеристики повинні відображатися в мові у формі лексичної одиниці ${ }^{28}$. Перші спроби довести цю гіпотезу полягали в пошуку відповідних лексем у словниках англійської та німецької мов. У 1936 р. Г. Оллпорт ${ }^{29}$ почав працювати над вибіркою та групуванням одиниць, а згодом Г. Айзенк $(1964 \text { р. })^{30}$ i Р. Каттелл (1977 p. $)^{31}$ за допомогою статистичного методу створили перші психометричні тести. Р. Макре і П. Коста (1989 р.) $)^{32}$ запропонували модель "Великої п’ятірки”, у якій виділили п'ять основних рис особистості та створили один 3 найпопулярніших психометричних інструментів. У 2004 р. американські психологи М. Ештоном і К. Лі ${ }^{33}$ запропонували розширити цю модель до шести чинників особистості та розробили новий тест, що набув популярності.

Інший важливий підхід до вивчення особистості виводиться з аналітичної психології швейцарського вченого К. Юнга ${ }^{34}$, в основі якої лежить ідея про виділення психологічних типів на підставі домінантних психологічних функцій, що визначають поведінку людини. К. Юнг уважав, що кожна людина розвиває тенденцію до використання певних ментальних функцій, які визначають іiі поведінку в певних ситуаціях. Такими дихотомічними функціями є "відчуття (сенсорика)" та "інтуійія", “мислення" і "почуття (переживання)”, за допомогою яких людина формує своє ставлення до довкілля - екстраверсійне (скероване зовні) чи інтроверсійне (скероване всередину). Перші дві функції відповідають за спосіб аналізу інформації (через органи чуття або за допомогою інтуїціiі), інші дві - за спосіб прийняття рішень (за допомогою логічного мислення або ж внутрішнього імпульсу-почуття).

${ }^{26} \mathrm{~F}$. J. L andy, Early influence on the development of industrial and organizational psychology, [in:] „Journal of Applied Psychology” 1997, No. 82, p. 467-477. 2005.

${ }^{27}$ L. A. Pervin, D. Cervone, O. P. John, Personality: Theory and research, New York

${ }^{28}$ F. Galton, Measurement of Character, [in:] „Fortnightly Review” 1884, No. 36, p. 179-185.

${ }^{29}$ G. W. All port,Becoming: Basic considerations for a psychology of personality, London 1969.

${ }^{30}$ H. J. Eys enck, S. B. G. Ey s e n c k, Manual of Eysenck Personality Inventory, London 1964.

${ }^{31} \mathrm{R}$. Catte 11, P. Kline, The scientific analysis of personality and motivation, New York 1977.

${ }^{32} \mathrm{R}$. R. Mc Crae, P. T. Jr. Costa, Reinterpreting the Myers-Briggs type indicator from the perspective of the Five-Factor model of personality, [in:] „Journal of Personality” 1989, No. 57, p. $17-40$.

33 M. C. Ashton, K. Lee, The HEXACO-60: A short measure of the major dimensions of personality, [in:] „Journal of Personality Assessment” 2009, No. 91, p. 340-345.

34 C. G. Jung, Psychological Types. Collected Works, Princeton 1971, Vol. 6. 
У 1962 р. ідею К. Юнга використали американські психологи К. Бріггз та I. Брігтз Маєрс ${ }^{35}$ для створення одного 3 найпопулярніших до тепер психометричних тестів - Індикатора Типів Маєрс-Бріггз (англійське загальновживане скорочення - “МВТІ”). Додавши ще дві дихотомічні функції — “думку” та "сприйняття", - що мали пояснити спосіб застосування домінантних функцій у напрямку зовні (екстраверсійно) чи всередину (інтроверсійно), психологи дали можливість розрізнити шістнадцять типів особистості. Сьогодні індикатор перекладено двадцятьма мовами світу, що свідчить про його широке застосування, зокрема в галузі психології праці.

Обидва підходи, хоч і знаходяться в опозиції, часто використовують як доповнення один до одного з метою більш усеохопного пізнання людської істоти. Досліджуючи особистість перекладача, необхідно брати до уваги не лише риси, за допомогою яких він вирізняється з-поміж фахівців у інших сферах, а й те, що переклад - це, як згадувалося раніше, "комплексна когнітивна діяльність”, що передбачає активування відповідних ментальних функцій. Досі вивчення психологічних особливостей особистості перекладача було доволі несистематичним з огляду на використання психологічних теорій, але все ж принесло цікаві результати.

Взаємозв'язок між професією перекладача та його особистістю зауважили давно. Ще 1968 р. британський учений Т. Сейворі в книзі The Art of Translation (Мистецтво перекладу) писав: „До знання мови та літературних здібностей перекладач мусить додати переживання, цікавість, ретельність та сумлінність" ${ }^{36}$.

К. Райс ${ }^{37}$ була першою серед перекладознавців, хто застосував психологічні вчення до опису особистості перекладача. Метою К. Райс було створення функційної теорії типів тексту, а тому їй здалось, що особистісні ознаки перекладача можуть сприяти якості перекладу певних типів тексту. Вона використала теорію німецького психолога Е. Шпрангера про шість типів характеру $(1922 \text { / } 1928 \text { р. })^{38}$ : теоретичний, економічний, естетичний, соціальний, агресивний і релігійний. На думку К. Райс, найкращим і універсальним перекладачем $\epsilon$ естетичний тип, теоретичний тип міг би добре перекладати технічні та філософські тексти, а агресивний тип найменше підходив би на роль перекладача. Незважаючи на брак практичних доказів своїх тверджень, К. Райс уважають ініціатором дослідження особистості перекладача. Вона показала новий напрямок для перекладознавчих розвідок. Зауважимо, що теза про можливий зв'язок між особистістю та типом тексту, яку запропонувала К. Райс, цікавить багатьох учених, але ще й досі не знайшла ані підтвердження, ані спростування.

Антропологічний підхід у перекладі продовжив британський перекладознавець Дж. Гендерсон у 1987 р. в монографії Personality and the Linguist: A comparison of the personality profiles of professional translators and conference interpreters / Особистість і філолог: порівняння рис особистості письмових та усних перекладачів ${ }^{39}$, що стала першим емпіричним дослідженням пробле-

\footnotetext{
${ }_{35}$ I. B. Myers, Manual: The Myers-Briggs Type Indicator, Palo Alto 1962.

36 T. S a v ory, The Art of Translation, London 1968, p. 36.

37 K. Re is s, Translation criticism - the potentials and limitations. Categories and criteria for translation quality assessment [Translated by E. F. R h od e s], London and New York $1971 / 2014$.

38 E. S pranger, Die Lebensformen/Types of Men (3rd ed.) [Translated by P. J. W. P ig or s ], New York 1922 / 1928.

$39 \mathrm{~J}$. A. Henders on, Personality and the linguist: A comparison of the personality profiles of professional translators and conference interpreters, Bradford 1987.
} 
ми психологічних чинників особистості перекладача. Учений застосував анкету шістнадцяти факторів особистості, яку розробив американський психолог Р. Кеттел $(1977 \text { р. })^{40}$, проектуючи ï на психолексичні дослідження й теорію рис з метою порівняння особистих профілів усних та письмових перекладачів. Дж. Гендерсон висунув гіпотезу про те, що професійні філологи вирізняються певним складом особистісних характеристик, на підставі яких можна виділити дві групи фахівців - усні та письмові перекладачі. Другою метою, яку ставив перед собою Дж. Гендерсон, було доведення факту впливу особистості на професійну діяльність перекладача i, як наслідок, необхідність ураховувати iї як один з впливових чинників у процесі навчання. У проекті Дж. Гендерсона взяло участь сто філологів, серед яких 65 письмових і 35 усних перекладачів. Статистичний аналіз результатів показав, що обидві групи характеризуються подібним складом рис і не мають статистично вагомих відмінностей. Було спростовано стереотип про те, що усні перекладачі - екстраверти, а письмові - інтроверти й нейтралізовано “переживання" про "роздвоєння особистості” тих, хто поєднує ці дві професії. Серед непередбачуваних відмінностей між представниками обох груп - письмові перекладачі більш прагматичні, а усні наділені багатшою уявою. Загалом, зріз особистості письмового перекладача можна окреслити так: “стриманий, розумний, емоційно стабільний, скромний, розважливий, сумлінний, сором'язливий, тямущий, самостійний, зібраний i консервативний (останнє підтверджено частково)" 41 . Щодо усного перекладача, то його особистість має такі ознаки: “товариський, розумний, впевнений у собі, безтурботний, відважний, самодостатній, залежний від суспільної думки та раціональний” ${ }^{2}$. Розвідка Дж. Гендерсона показала, що особистість є важливим чинником у процесі набуття та розвитку професійних компетенцій перекладача, але зацікавлення цією проблемою на деякий час зникло.

У 1996 р. австрійський перекладознавець I. Курц ${ }^{43}$ спробувала застосувати “орієнтаційну модель комунікативних цілей” (переклад автор. - О. Л.-П.), розроблену французьким психологом П. Кассе ${ }^{44}$ у 80 -х роках минулого століття для порівняльного аналізу особистих преференцій письмових та усних перекладачів. Ця модель передбачає, що кожна людина надає перевагу одному із чотирьох стилів спілкування: 1) зосереджений на дії (що?), 2) зосереджений на процесі (як?), 3) зосереджений на людині (колективна праця), 4) зосереджений на ідеї (чому?). У дослідженні взяло участь сімдесят осіб: 31 студент молодших курсів напрямку “переклад” та 39 студентів старших курсів того ж напрямку. Їхнім завданням було заповнити анкету відповідями про особистість письмового та усного перекладача. Результати аналізу показали, що письмовий перекладач зосереджений на процесі та людині, а усний — на людині та діï. Звертаючись до першочергової ідеї про дуалізм у підході до об'єкту дослідження в перекладознавстві, такий висновок австрійської дослідниці ще раз підтверджує необхідність аналізувати процес перекладу в зіставленні з кінцевими продуктом крізь призму особистості перекладача (людського фактору). Одним

40 R. Cattell, P. Kline, The scientific analysis of personality and motivation, New York 1977.

41 J. A. Henders on, Personality and the linguist..., p. 125.

${ }^{42}$ Ibidem.

43 I. Kurz, E. Base1, D. Chiba, W. Patels, J. Wolfframm, Scribe or actor? A survey paper on personality profiles of translators and interpreters, [in:] „The Interpreters' Newsletter" 1996, No. 7, p. 3-18.

${ }^{44}$ P. Cass e, Training for the Cross-Cultural Mind: A Handbook for Cross-Cultural Trainers and Consultants, Washington 1981. 
із заключних коментарів дослідниці був заклик до детальнішого опису особистості перекладача, оскільки такий аналіз зміг би відкрити нові горизонти для перекладацьких досліджень.

Французький перекладач і науковець Т. Барбоні ${ }^{45}$ використала свій досвід психоаналізу та клінічної психології в теоретичній спробі визначення особистих факторів, що впливають на процес перекладу. Подібно до К. Райс, дослідниця 3 власних спостережень зауважила можливість зв'язку між чинниками особистості та здібністю перекладати певні типи тексту. Т. Барбоні вважає, що переклад - це напружений вид діяльності, тому кожен перекладач випрацьовує власні механізми захисту, що відбиваються на його перекладацькій стратегії та тексті перекладу. Т. Барбоні стверджувала, що такі механізми - це схема поведінки перекладача, що залежить від індивідуального набору рис особистості, які формуються ще в дитинстві та часто пов'язані із суспільним становищем автора перекладу.

У 2009 р. проблема психологічних чинників особистості перекладача привернула увагу британських учених, зокрема С. Губшер Девідсон ${ }^{46}$, яка зробила чи не першу спробу поєднати детальний аналіз процесу перекладу та якості вихідного тексту крізь призму типів особистості. Методологічну основу iï дослідження побудовано на протоколах “думки вголос" (англійською мовою "Think-Aloud Protocols") для отримання процесуальних даних, спеціально розробленій анкеті для оцінювання якості тексту, а також відомому психометричному тесті - Індикаторі Типів Маєрс-Бріггз. Двадцятеро студентів напрямку “переклад" отримало завдання перекласти текст туристичного характеру з французької мови (друга робоча мова) на англійську (перша робоча мова), а потім пройти психометричний тест. Працюючи над перекладом, учасники повинні були озвучувати хід своїх думок. На етапі аналізу експерти оцінювали кожен переклад згідно з критеріями, поданими в анкеті для оцінювання якості вихідного тексту. За результатами дослідження вагомою виявилась дихотомія психологічних функцій інтуїиія-сенсорика: ті учасники, які на підставі психометричного тесту надавали перевагу інтуїції для прийняття рішень, ефективніше працювали у процесі перекладу і мали значно вищі результати якості вихідного тексту, ніж прибічники сенсорики-відчуття. Такий висновок свідчить про те, що переклад вимагає глибинного, пророчого мислення, а не логічного вибору найближчих відповідників. 3 огляду на роль інтуїції в професії перекладача саме вона $\epsilon$ наступним предметом дослідження С. Губшер Девідсон, яка настільки захопилася цією темою, що здобула другу вищу освіту в напрямку “психологія” й далі займається вивченням особистості перекладача.

Усі вищезгадані спроби описати внутрішній, тобто особистісний, бік перекладацької діяльності, указують на те, що перекладач і справді вирізняється унікальним складом психологічних ознак, які в різний спосіб впливають на вибір його перекладацької стратегії, а також на кінцевий продукт його праці. Однак на цей час бракує розвідок, що могли б відповісти хоча б на такі питання: які чинники особистості характеризують перекладача художніх текстів на відміну від перекладача офіційних документів або технічних інструкцій; чи можливо простежити розвиток особистості перекладача під впливом досвіду;

${ }^{45}$ T. Barboni, Inconscient et traduction, [in:] C. Lej e un e (ed.), „Théorie et Pratique de la Traduction" 1999, No. 3, p. 23-33.

46 S. Hubscher Davidson, Personal diversity and diverse personalities in translation: A study of individual differences, [in:] „Perspectives: Studies in Translatology” 2009, Vol. 17, No. 3, p. $175-192$. 
які риси особистості можна спроектувати на якість перекладу; як психологічні чинники відображаються в процесі перекладу під час використання довідкових матеріалів, у вигляді частоти й тривалості пауз, змінності рішень та способі затвердження остаточних варіантів перекладу; як особистість перекладача виявляється на етапі перевірки цілого тексту самим перекладачем? Детальний аналіз процесуальних даних та вихідного тексту в поєднанні з результатами психометричних інструментів методом тріангуляції ${ }^{47}$ (порівняння й зіставлення результатів різних методів аналізу) допоможе розкрити таємниці “чорної скриньки" свідомості перекладача і краще зрозуміти ментально складний і багатоетапний процес роботи над перекладом тексту.

47 F. Alves (ed.), Triangulating translation: Perspectives in process oriented research, Amsterdam 2003. 